Igor M. Drapkin a), Anna A. Gainetdinova ${ }^{\text {b) }}$, Aksanat Zh. Panzabekova ${ }^{\text {) }}$

a, b) Ural Federal University, Ekaterinburg, Russian Federation

c) Institute of Economics CS MES RK, Almaty, Republic of Kazakhstan

a) http://orcid.org/0000-0002-5989-8463, e-mail: i.m.drapkin@mail.ru

c) http://orcid.org/0000-0002-6389-9637

\title{
Determinants of High-tech Export in CEE and CIS Countries
}

Any government strives to stimulate export activity in high-tech sectors of its economy. Surprisingly, there are few empirical papers on the determinants of high-tech export to date. This study analyses the economies of Central and Eastern Europe (CEE) and the Commonwealth of Independent States (CIS) due to the differences they experienced in the transition period. To this end, we used the Balassa index, which is based on the concept of revealed comparative advantages. The research examines 73 groups of products from the automotive, chemical, mechanical engineering, electronics and electrical engineering industries in 27 countries from 1995 to 2018. Principal component analysis helped generate an indicator of comparative advantage of hightech industries for each country in each year. It is revealed that CEE countries, as well as the Baltic countries, have achieved significant success in the development of high-tech sectors of the economy, while the CIS countries have shown practically no progress in this direction. The article tests hypotheses on the impact of resources, foreign trade, macroeconomy and innovation on export activity in the country. The following factors stimulate the export growth in high-tech industries of the studied countries: level of wages and resource prices, openness of the economy to foreign trade; tax rate; unemployment rate; quality of human capital. We did not find empirical evidence of the positive impact of inflation, inflows of direct foreign investment, and the level of research and development $(R \& D)$ costs on the volume of high-tech export of the examined economies.

Keywords: export, export structure by industry, high-tech industries, revealed comparative advantage, Balassa index, determinants of growth in high-tech industries, competitiveness of industries, export stimulation, post-communist economies, structural problems in the Russian economy

\section{Acknowledgements}

The article has been prepared with the support of Russian Foundation for Basic Research (the project No. 18-010-01190 "Models of innovation development factors and comparative advantages analysis in the Russian economy "). Aksanat Panzabekova would like to thank the Science Committee of the Ministry of Education and Science of the Republic of Kazakhstan (Grant No. AP09260795).

For citation: Drapkin, I. M., Gainetdinova, A. A. \& Panzabekova, A. Zh. (2021). Determinants of High-tech Export in CEE and CIS Countries. Ekonomika regiona [Economy of region], 17(2), 486-501, https://doi.org/10.17059/ekon.reg.2021-2-10

\footnotetext{
1 () Drapkin, I. M., Gainetdinova, A. A. \& Panzabekova, A. Zh. Text. 2021.
} 
И. М. Драпкин ${ }^{\text {a) }}$, А. А. Гайнетдинова ${ }^{\text {б) }}$, А. Ж. Панзабекова ${ }^{\text {) }}$ а, б) Уральский федеральный университет им. первого Президента России Б. Н. Ельцина, Екатеринбург, Российская Федерация

в) Институт экономики КН МОН РК, Алматы, Республика Казахстан a) http://orcid.org/0000-0002-5989-8463, e-mail: i.m.drapkin@mail.ru в) http://orcid.org/0000-0002-6389-9637

\section{Факторы конкурентоспособности высокотехнологичных отраслей в странах СНГ и Центральной и Восточной Европы}

Несмотря на то, что государства во всем мире стремятся к увеличению экспорта высокотехнологичных отраслей, в современной научной титературе немного работ, посвященных этой проблеме. Целью статьи является изучение развития экономики в странах Содружества Независимых Государств (СНГ) и Центральной и Восточной Европь (ЦВЕ) в переходный период. В исследовании используется индекс Баласса, основанный на концепции выявленного сравнительного преимущества. Объектом анализа являются 73 группь товаров автомобильной, химической, машиностроительной отраслей, а также электроники и электротехники в 27 странах за период 1995-2018 г2. При помощи метода главных компонент сбормирован индекс сравнительного преимущества высокотехнологичных отраслей для каждой страны за каждый год. Показано, что страны Центральной и Восточной Европь и Балтии добились существенных успехов в развитии высокотехнологичных секторов экономики, в то время как в странах СНГ прогресс в этом направлении практически отсутствует. Для выявления статистических взаимосвязей использован регрессионно-корреляицонный анализ, для оценки данных применен метод наименьщих квадратов с фиксированными эффектами. Выявлены факторы, стимулирующие рост экспорта в высокотехнологичных отраслях исследуемых стран: внешнеторговая открытость экономики, заработная плата и цены на ресурсы, налоговая нагрузка, уровень безработииы и человеческий капитал. Авторам не удалось обнаружить подтверждений положительного влияния притоков прямых иностранных инвестиций, уровня затрат на НИОКР и также качества человеческого капитала на объем экспорта высокотехнологичных секторов в рассматриваемых странах.

\section{Acknowledgements}

Исследование выполнено при финансовой поддержке РФФИ (проект № 18-010-01190 «Модели анализа факторов инновационного развития и сравнительных преимуществ в российской экономике»). Аксанат Панзабекова выражает благодарность Комитету науки Министерства образования и науки Республики Казахстан (грант № AP09260795).

Ключевые слова: экспорт, отраслевая структура экспорта, высокотехнологичные отрасли, выявленное сравнительное преимущество, индекс Баласса, детерминанты роста высокотехнологичных отраслей, конкурентоспособность отраслей, стимулирование экспорта, посткоммунистические страны, структурные проблемы российской экономики

Для цитирования: Драпкин И. М., Гайнетдинова А. А., Панзабекова А. Ж. Факторы конкурентоспособности высокотехнологичных отраслей в странах СНГ и Центральной и Восточной Европы // Экономика региона. 2021. Т. 17, вып. 2. С. 486-501. https://doi.org/10.17059/ekon.reg.2021-2-10

\section{Introduction}

The problems of the industrial structure of the Russian economy are well known. Oil and gas exports largely contribute to federal budget revenues. In the planning documents of the Ministry of Finance of the Russian Federation, their indicative value is $61 \%$ for 2020 and $62 \%$ for $2021 .{ }^{1}$ During the last 30 years of reforms, the raw material specialisation of Russian exports has only increased: the share of mineral products in total

\footnotetext{
${ }^{1}$ Ministry of Finance of the Russian Federation. 2018. Main directions of budgetary, tax and customs tariff policy for 2019 and for the planning period of 2020 and 2021. Retrieved from: https://www.minfin.ru/ru/document/?id_4=123006-proekt_ osnovnykh_napravlenii_byudzhetnoi_nalogovoi_i_tamozhenno-tarifnoi_politiki_na_2019_god_i_na_planovyi_period_2020_i_2021_godov (Date of access: 18.07.2020).
}

exports in 2000 was $53.8 \%$, while in 2019 it was $63.3 \% .^{2}$

Due to the raw material specialisation, the Russian economy is unstable and critically dependent on external factors. At the same time, diversification of the industrial structure by strengthening the sectors with high added value will help solve the problems associated with sustainability of economic growth, creation of highly productive jobs, increase of the population's well-being and quality of life.

After the disintegration of the bloc of socialist countries in Central and Eastern Europe and

\footnotetext{
2 Information from the websites of Federal State Statistics Service (www.gks.ru) and the Federal Customs Service (www. customs.ru).
} 
Table 1

Dynamics of development indicators of the countries of Eastern Europe and the former Soviet Union (USSR)

\begin{tabular}{|l|c|c|c|c|c|c|c|c|}
\hline \multirow{2}{*}{ Country } & \multicolumn{3}{|c|}{$\begin{array}{c}\text { Gross domestic product (GDP) } \\
\text { per capita, USD }\end{array}$} & $\begin{array}{c}\text { The share of mid- and high-tech } \\
\text { exports in the total export of } \\
\text { industrial products, \% }\end{array}$ & \multicolumn{2}{c|}{$\begin{array}{c}\text { The value of exported goods, } \\
\text { USD (year 2000= 100) }\end{array}$} \\
\cline { 2 - 10 } & $\mathbf{1 9 9 5}$ & $\mathbf{2 0 1 9}$ & Change & $\mathbf{1 9 9 5}$ & $\mathbf{2 0 1 7}$ & $\mathbf{1 9 9 5}$ & $\mathbf{2 0 1 8}$ & Change, times \\
\hline Poland & 6539 & 17386 & 10847 & 36.7 & 55.2 & 72.1 & 821 & 11.4 \\
\hline Hungary & 8957 & 17466 & 8509 & 45.6 & 75.8 & 45.6 & 446 & 9.8 \\
\hline Czech Republic & 13462 & 23833 & 10371 & 45.5 & 69.9 & 74.5 & 695 & 9.3 \\
\hline Latvia & 5140 & 16697 & 11557 & 25.8 & 42.7 & 69.8 & 863 & 12.4 \\
\hline Lithuania & 5318 & 18427 & 13109 & 34.1 & 42.8 & 71.0 & 875 & 12.3 \\
\hline Estonia & 7209 & 20741 & 13532 & 32.1 & 50.2 & 48.1 & 445 & 9.3 \\
\hline Russia & 5928 & 12011 & 6083 & 37.6 & 28.6 & 78.4 & 422 & 5.4 \\
\hline
\end{tabular}

Source: The World Bank, the authors' calculations.

the collapse of the USSR, a large number of countries faced similar problems related to the legacy of the planned economy, hyperinflation, decrease of real incomes of the population, and state budget deficits. At the same time, many countries in this group have already undergone a successful transformation. Table 1 presents individual indicators of Russia's development in comparison with three Eastern European countries (Hungary, the Czech Republic, Poland), as well as three Baltic republics of the former USSR (Latvia, Lithuania and Estonia). In this group of countries, Russia demonstrated the lowest growth in GDP per capita in absolute terms for the period 1995-2019 (\$6083, compared, for example, with \$13532 in Estonia, \$13109 in Lithuania and \$10847 in Poland). Russia is the only country in the group whose share of mid- and hightech exports in total exports of industrial products decreased from $37.6 \%$ to $28.6 \%$ over the period of 1995-2017 (this indicator increased from $45.6 \%$ to $75.8 \%$ in Hungary, from $45.5 \%$ to $69.9 \%$ in the Czech Republic, from 36.7 \% to $55.2 \%$ in Poland). From 1995 to 2018, the value of exports in nominal terms increased only 5.4 times in Russia, compared to 12.4 times in Latvia, 12.3 times in Lithuania and 11.4 times in Poland.

Nowadays, an increase in exports of high-tech industries is one of the main priorities of the countries involved in the system of world economic relations. Identification of factors contributing to the development of these industries is important for both understanding the mechanisms triggering growth in certain national industries and developing measures aimed at improving the efficiency of state industrial policies.

This study analyses factors affecting exports of high-tech industries in Central and Eastern Europe (CEE) and the Commonwealth of Independent States (CIS). ${ }^{1}$

\footnotetext{
${ }^{1}$ A complete list of countries can be seen in Table 3.
}

\section{Literature Review}

This article examines external factors (from the point of view of the exporting firm) that affect export flows in the country.

Currently, there is a significant number of studies aimed at identifying the determinants of exports in the country. Most of them analyse the country's exports using three indicators: increase in nominal export volumes, export diversification, and export sophistication. This section is devoted to structuring the well-known factors influencing export activity.

The direction and volume of intercountry trade flows (exports and imports) in the world economy can be explained using the gravity approach. It stipulates that the volume of exports from country $j$ to country $i$ is directly proportional to the GDP of countries I and $j$ and inversely proportional to the distance between them. Tinbergen is considered a pioneer in the application of the gravity approach to the analysis of international trade [1]. Later, the works of Anderson \& van Wincoop [2], Egger [3], Silva \& Tenreyro [4] and others made an important contribution to the development of methodological approaches to the empirical assessment of the gravity model of international trade. In addition to gravitational factors, the volume of exports from country $j$ to country $i$ also depends on the amount of differences between them: Kónya [5] argued the importance of cultural differences, Gómez-Herrera [6] - linguistic, Francois and Manchin [7] - institutional ones.

According to the Heckscher-Ohlin neoclassical model of international trade, the structure and volume of a country's exports is determined by its resource endowment. Based on data from the Organisation for Economic Co-operation and Development (OECD) countries, Gustavsson, Hansson \& Lundberg [8] revealed a positive relationship between the volume of exports in an industry and the volume of a country's resources 
used by this industry, while the relationship between the volume of exports and the prices of used resources is negative. Naudé \& Gries [9] obtained similar results when analysing the export in South African regions. Accumulated physical capital is an important export driver in Marconi and Rolli's work on emerging markets [10], as well as Thangamani's work on Sri Lanka export data [11].

Many studies examine the impact of the quality of workforce on the country's export activities. Based on data on 79 countries from 1962 to 2000, Agosin, Alvarez \& Bravo-Ortega [12] showed that countries with higher quality human capital have a more diversified export structure. The International Monetary Fund (IMF) study found that the complexity of exports correlates with the level of education in the group of low-income countries [13]. Analysing the structure of exports by revealing comparative advantages of 16 developing countries, Marconi \& Rolli [10] showed that low wages determine comparative advantages in both low-tech and high-tech sectors. Low quality of human capital negatively affects the value of exports in the countries under consideration.

The country's foreign economic indicators are a significant export factor. The openness of the economy has a positive effect on the volume of exports (see, for example, the works of Parteka \& Tamberi [14] and Mau [15]). Based on data on 175 countries from 1980 to 2007, Iwamoto \& Nabeshima [16] showed that foreign direct investment (FDI) leads to export diversification. While studying the export activity of Indian firms, Banga found that FDI from American firms leads to the diversification of Indian firms' exports, while FDI from Japanese firms does not have a significant impact on Indian exports [17]. The transfer of technology from foreign to national companies contributes to the growth of exports of the latter, as shown in the work of Gorg \& Greenway [18]. Based on data on the economy of Sri Lanka, Thangamani [11] concluded that involvement of a foreign partner allows the company to gain access to the technology for entering foreign markets.

A country's participation in global value chains is directly related to the characteristics of its export activity. The quality of the country's export flows is affected by the volume of the components' import [19]. On the one hand, imported components of better quality contribute to an increase in the quality of exported products [20]. On the other hand, the high quality of imported components contributes to the transfer of technologies in the country, also leading to an increase in exports
[21]. Participation of countries in regional economic associations is another foreign economic factor stimulating exports. Using the example of the cheese industry in the European Union (EU), Balogh \& Jambor [22] show that the EU membership is a significant factor in stimulating exports. Similar findings are included in the OECD report for the EU meat industry [23].

The country's macroeconomic indicators have a significant impact on export volumes. The high cost of credit, as well as the volatility and overvaluation of the exchange rate, negatively affect export diversification [12]. The resilience of the national financial system contributes to the growing export sophistication, according to the IMF report [13]. Sulaiman and Saad described a positive relationship between economic growth and exports in Malaysia [24].

Innovation activity is the most important determinant of exports. Gustavsson, Hansson \& Lundberg [8], as well as Muratoğlu \& Muratoğlu [25], demonstrated that research and development $(R \& D)$ spending stimulates competitive advantages and export growth in OECD countries. Analysing the activities of industrial enterprises in Sweden and Finland, Blomstrom \& Kokko [26] showed that the state policy in the field of stimulating innovation activity contributes to the growth of high-tech exports in the country.

Infrastructure investment decreases production costs for firms and increases exports [13].

Many studies show the significance of the development of institutions in the country as a factor in export activities. Analysing companies of different ages and sizes in emerging economies, LiPuma, Newbert \& Doh [27] found that the development of institutions has a significant influence on all groups of companies. Nguyen \& Wu [28] showed that export volumes of Vietnamese firms are positively correlated with the quality of public administration in the country. Li, Vertinsky \& Zhang [29] obtained similar results based on data on export activity of Chinese firms.

Summarising the results of the literature review on the research topic, we can identify the following groups of factors that affect the quantitative and qualitative indicators of the country's exports: gravitational, resource-related, foreign economic, macroeconomic, innovative, infrastructural and institutional. At the same time, the determinants of export growth are not universal for different groups of countries and for different types of industries. Studies of the export activity factors in post-communist countries and hightech sectors are sporadic. This article contributes to filling the identified gap. 


\section{Hypotheses}

One empirical study cannot provide an assessment of all factors affecting the volume of hightech exports in a country. Based on the literature review, as well as on data available for analysis, our study examines the influence of four groups of factors: foreign economic, macroeconomic, resource-related, and innovative. We formulated the following research hypotheses.

H1. A rise in resource prices in the country leads to an increase in high-tech exports. Investments in high-tech products in the modern economy are largely determined by the limitation of resources, primarily, labour and raw materials. As a rule, countries with cheap labour and high availability of raw materials specialise in labour-intensive upstream production. It is believed that the high price of resources stimulates the development of high-tech industries in the country, and, consequently, the export of high-tech products.

H2. An increase in foreign economic activity in the country stimulates the growth of high-tech exports. In the modern economy, the structure of world production is fragmented by country within global value chains (GVCs). As a rule, high-tech products are traded within GVCs, since multinational companies (MNCs) are a source of demand in production chains, and MNCs require high-tech components for their production. It is assumed that an increase in the country's foreign economic activity, manifested in an increase of foreign trade and foreign direct investment, stimulates the interaction of national companies with external partners. In turn, this encourages national companies to make various improvements to their product, increasing their competitiveness in international markets and, ultimately, causing an increase in the export of high-tech products.

H3. Macroeconomic stability in the country has a positive effect on the volume of exports of hightech products. The stable macroeconomic position of the country is a factor that reduces investment risks. Two of the most important macroeconomic indicators in the country are considered, namely, inflation and unemployment. Firstly, a decrease in inflation leads to a decrease in interest rates and, consequently, to an increase in the number of implemented investment projects. Secondly, an increase in the unemployment rate, which may reflect the availability of labour in the country, negatively affects the industrial development due to the deterioration in the quality of life of the population.

H4. A reduction of the tax rate in the country leads to an increase in the volume of high-tech exports. The tax rate, influencing the cost of con- ducting business in the country, has a significant impact on implemented projects. We can predict a negative relationship between the tax rate and the export in high-tech industries for two reasons. Firstly, a decrease in the tax rate leads to an increase in both financial efficiency and the number of investment projects implemented in the country. Secondly, since companies face additional costs when exporting (compared to supplying the domestic market), tax cuts will lead to the implementation of export projects that were unprofitable under high tax.

H5. The level of innovation activity and the quality of human capital have a statistically significant positive impact on exports in high-tech industries. R\&D investment is an essential condition for the development of enterprises in the modern economy. At the same time, enterprises in high-tech industries invest significantly more in R\&D compared to enterprises in the traditional sector [23]. In this regard, it can be assumed that the level of innovation activity in the economy is a stimulating factor in the development of the high-tech sector.

The quality of human capital is also an important condition for creating new technologies, because the lack of highly qualified specialists can restrict the economic development. At the same time, a higher level of human capital stimulates entrepreneurial activity in the country, which should have a positive effect on activity in hightech sectors of the economy.

The share of urban population in the total population of the country is another crucial indicator. Firstly, the urban environment generates various agglomeration effects associated with the growth of business activity and the productivity of enterprises [30]. Secondly, rural residents are usually not involved in high-tech production.

\section{Data and Descriptive Statistics}

The Balassa Index [31], based on the concept of comparative advantage, is used in this study to assess the value of a country's exports at the industry level. The index is calculated as the proportion of exports of a certain product in the total volume of a country's exports divided by the proportion of the same product in the world export volume:

$$
B_{i j}=\frac{X_{i j}}{X_{i t}} / \frac{X_{w j}}{X_{w t}},
$$

where $X_{i j}$ and $X_{w j}$ - the amount of revenue from the export of product $j$ for country $i$ and the world export of product $j$, respectively; $X_{i t}$ and $X_{w t}-$ the total export volume of the selected country and the world in general, respectively. 
An index value greater than one indicates the presence of a comparative advantage in the industry in the considered country, while a value less than one shows its absence. In this study, we proceed from the assumption that the presence of a comparative advantage in an industry shapes its competitiveness in the global market, which implies a higher level of exports compared to the same industries in other countries.

Data in the public domain presented on the UNCTAD statistical portal are the basis for calculating the index of comparative advantage of high-tech industries. We examined the data on 27 countries of Eastern Europe and the CIS covering the period from 1995 to $2018 .{ }^{1}$

In accordance with the Third Revision of the Standard International Trade Classification $(\text { SITC })^{2}, 73$ groups of mid- and high-tech products were classified as products of high-tech industries. The group of mid-tech production includes complex technologies with moderately high investments in research and development, which require advanced skills and long training. This group comprises automotive, chemical and mechanical engineering products. The group of high-tech production includes products with rapidly changing advanced technologies and high investments in research and development, namely, electronics and electrical engineering. In the database, the value of the comparative advantage index varies from 0 (the country does not export a specific product) to 34.94 (Ukraine's exports of the group of products "Railway transport and railway materials" in 2011), with an average value of 0.712 .

To simplify the analysis of available data, it is advisable to have a single indicator characterising the identified comparative advantage of high-tech industries for each country for each year (for brevity, we will denote it as the CAHTI index).

We construdcted this index using the principal component analysis, one of the main advantages of which is the minimum loss of informa-

\footnotetext{
${ }^{1}$ The choice of 1995 as the starting year for the study is due to the fact that data for an earlier period for most of the indicators used in the work are not available to the authors.

${ }^{2}$ SITC classification 3 (SITC Rev. 3 - Standard International Trade Classification, Revision 3) is a basic classification recommended by the UN to be used by all countries for data on exports and imports. It ensures comparability of data on foreign trade statistics. It is used when reporting trade data by international organisations such as UNCTAD, World Bank, etc. It was introduced by Lall [32]. The principle of selection of product groups takes into account the following: the materials used in their production, the stage of production, the purpose of the product, the importance of the product in international trade, and technological changes (https://unstats.un.org/unsd/ classifications/Family/Detail/14).
}

tion during the data dimensionality reduction. ${ }^{3}$ The CAHTI index is in the range from -2.46 to 4.70 with an average value of zero. ${ }^{4}$ The generated index explains approximately $94 \%$ of the variation in the original set of variables on the basis of which it was calculated. Consequently, the negative value of the CAHTI index indicates a relatively weak level of development of high-tech exports in the country, while the positive value indicates a higher development of this sector in comparison with the average level for all countries.

Table 2 shows the dependent and explanatory variables used to test the formulated hypotheses. For better comparability of the indicators included in the model, most of the variables measured in dollars (except wages) are recalculated per capita. In order to have regressors comparable in dimension, all variables, except those measured in fractions, were logarithmised.

Table 3 provides information on the change in this index in the examined countries. The initial value is the average value of the index for the first two years of the observation period, the final value is the average value of the index for the last two years. At the beginning of the period, 18 out of 27 countries had a negative value of the CAHTI index, which was probably caused by the non-market nature of the economy of these countries. Slovenia (2.85), Czech Republic (2.62), Hungary (1.62) and Slovakia (1.30) were initially characterised by high indicators of the CAHTI index. The rest of the countries in the group with a positive

\footnotetext{
${ }^{3}$ Principal component analysis is a multivariate statistical analysis technology used to reduce the dimensionality of feature space while minimizing useful information loss. This method was proposed by K. Pearson in 1901, and then, in the 1930s, was developed in detail by the American economist and statistician G. Hotelling. From a mathematical point of view, the principal component analysis is an orthogonal linear transformation that maps data from the original feature space to a new space of lower dimension. In this case, the first axis of the new coordinate system is constructed in such a way that the variance of the data along it is maximal. The second axis is orthogonal to the first one, so that the data variance along it is maximal of the remaining possible, etc. The first axis is called the first principal component, the second one is called the second, etc. [33]. Principal component analysis is widely used in economic research, where regression-correlation analysis is used: when constructing socio-economic indices [34], when analysing the factors of economic growth [35], when assessing risks in financial markets [36], when assessing the quality of institutions at the country level [37] and many others.

${ }^{4}$ Since the first step of the principal component analysis is the centring of the variables (geometric transfer of the coordinate centre to the centre of the observation cloud), the generated value of the CAHTI index has both negative and positive values, despite the fact that the value of the Balassa index lies only in the region of non-negative values.
} 
Dependent variable and regressors in the model

\begin{tabular}{|c|c|c|}
\hline Variable & Measurement units & Data source \\
\hline \multicolumn{3}{|c|}{ Dependent variable } \\
\hline $\begin{array}{l}\text { Comparative advantage in } \\
\text { high-tech industries }\end{array}$ & Index & $\begin{array}{l}\text { United Nations Conference on Trade and } \\
\text { Development (UNCTAD), the authors' calculations }\end{array}$ \\
\hline \multicolumn{3}{|c|}{ Tax rate and the resource prices } \\
\hline Wages & USD (log.) & International Labour Organisation (ILO) \\
\hline Gasoline price & USD (log.) & World Bank \\
\hline \multicolumn{3}{|c|}{ Indicators of foreign economic activity } \\
\hline Openness & (Export + Import) / GDP & World Bank \\
\hline Import & million USD per capita $(\log )$ & World Bank \\
\hline Foreign direct investment & million USD per capita (log) & UNCTAD \\
\hline \multicolumn{3}{|c|}{ Indicators of macroeconomic stability } \\
\hline Inflation & $\%$ & World Bank \\
\hline Unemployment & $\%$ & ILO \\
\hline Taxes & $\begin{array}{c}\text { Share of tax revenues in the structure } \\
\text { of the country's budget revenues }\end{array}$ & ICTD/UNU-WIDER \\
\hline \multicolumn{3}{|c|}{ Innovative activity and quality of human capital } \\
\hline $\mathrm{R} \& \mathrm{D}$ & share of expenditure in GDP & World Bank \\
\hline Patents & number per capita (log.) & World Bank \\
\hline Human capital & Index & World Bank \\
\hline Effects of urbanisation & $\begin{array}{l}\text { Share of urban population in the } \\
\text { country }\end{array}$ & World Bank \\
\hline
\end{tabular}

Source: compiled by the authors.

Dynamics of the index of comparative advantage of high-tech industries in the CIS and Eastern Europe

\begin{tabular}{|c|c|c|c|}
\hline & Initial value & Final value & Change \\
\hline Hungary & 1.62 & 4.24 & +2.62 \\
\hline Czech Republic & 2.62 & 3.79 & +1.17 \\
\hline Poland & 0.03 & 2.53 & +2.50 \\
\hline Slovakia & 1.30 & 2.33 & +1.03 \\
\hline Slovenia & 2.85 & 2.26 & -0.59 \\
\hline Lithuania & 0.24 & 1.89 & +1.65 \\
\hline Romania & -1.07 & 1.80 & +2.87 \\
\hline Croatia & 0.16 & 1.46 & +1.30 \\
\hline Estonia & 0.26 & 1.45 & +1.19 \\
\hline Bulgaria & 0.19 & 1.41 & +1.22 \\
\hline Serbia & -0.78 & 1.05 & +1.83 \\
\hline Belarus & -0.90 & 0.74 & +1.64 \\
\hline Montenegro & -0.78 & 0.40 & +1.18 \\
\hline Latvia & -0.55 & 0.32 & +0.87 \\
\hline North Macedonia & -1.46 & -0.16 & +1.30 \\
\hline Bosnia and Herzegovina & -1.24 & -0.36 & +0.88 \\
\hline Tajikistan & -1.18 & -1.20 & -0.02 \\
\hline Georgia & -1.37 & -1.27 & +0.10 \\
\hline Ukraine & -0.68 & -1.32 & -0.64 \\
\hline Turkmenistan & -1.36 & -1.59 & -0.23 \\
\hline Moldova & -1.42 & -1.60 & -0.18 \\
\hline Kyrgyzstan & -1.20 & -1.71 & -0.51 \\
\hline Russia & -1.88 & -1.84 & +0.04 \\
\hline Albania & -1.93 & -1.96 & -0.03 \\
\hline Armenia & -1.32 & -2.19 & -0.87 \\
\hline Kazakhstan & -1.68 & -2.34 & -0.66 \\
\hline Azerbaijan & -1.47 & -2.43 & -0.96 \\
\hline
\end{tabular}

Source: compiled by the authors. 
index value at the beginning of the period had indicators that were slightly above zero. At the end of the examined period, countries were clearly divided into two groups. All Baltic countries and all Eastern European countries, except for Slovenia and Albania, have significantly increased the export of high-tech industries, which led to an increase in their CAHTI index. At the same time, there was a drop in the CAHTI index in most of the CIS countries. The exception is Belarus $(+1.64)$, where the value of this index increased, as well as Russia $(+0.04)$, Georgia $(+0.1)$ and Tajikistan $(-0.02)$, where the value of the index remained virtually the same.

To identify patterns in the dynamics of the index of comparative advantages of high-tech industries, we analysed the most important development indicators in three countries with the greatest increase (Romania, Hungary, Poland - hereinafter group 1) and the largest decrease (Kazakhstan, Azerbaijan, Armenia - hereinafter group 2) in the CAHTI index for the considered period (see Table 4).

According to Hypothesis 1, the development of high-tech industries in the country is influenced by resource prices. In the reviewed period, all countries experienced a multiple increase in wages ( 2.1 times (minimum increase) in Azerbaijan, 4.9 times (maximum) increase in Armenia). At the same time, the level of wages in countries with an increase in the CAHTI index (\$1136 on average at the end of the reviewed period) significantly exceeds this indicator in countries with a decrease in the CAHTI index (\$321, respectively). Table 4 shows the gasoline price as one of the indicators of resource prices in the studied countries. It is higher in Romania, Hungary, and Poland than in Azerbaijan, Armenia, and Kazakhstan.

Additionally, it is necessary to analyse macroeconomic indicators of the countries. The average growth rate of nominal GDP in Group 2 exceeded this indicator in Group 1. The inflation rate for the reviewed period has decreased in all countries. Currently, the inflation rate in Romania (2.9\%), Hungary (2.6\%) and Poland (1.9\%) is roughly the same as in Armenia (1.8\%), but it is at a much lower level than in Kazakhstan (10.9\%) and Azerbaijan (7.4\%). Currently, the unemployment rate in Romania (4.5\%), Hungary $(3.9 \%)$ and Poland $(4.4 \%)$ is at the same level as in Azerbaijan (5.0 \%) and Kazakhstan (4.9\%), but it is significantly lower than this indicator in Armenia (16.7 \%). Tax rates in Group 1 are much higher than in Group 2.

After conducting a similar analysis for the indicators of imports, R\&D, patent activity, human capital development, and urbanisation (the values of which are presented in Table 4), we drew the following conclusions regarding the studied countries. Firstly, more expensive resources in the country (in particular, higher labour costs and higher fuel costs) stimulate the development of high-tech sectors of the economy. Secondly, higher levels of indicators of foreign economic activity - in particular, imports and FDI volume are associated with a higher value of the CAHTI

Table 4

Key indicators of countries with the highest increase and decrease in the CAHTI index

\begin{tabular}{|c|c|c|c|c|c|c|c|c|c|c|c|c|}
\hline \multirow{3}{*}{ Indicator } & \multicolumn{6}{|c|}{ Maximum increase in the CAHTI index } & \multicolumn{6}{|c|}{ Maximum decrease in the CAHTI index } \\
\hline & \multicolumn{2}{|c|}{ Romania } & \multicolumn{2}{|c|}{ Hungary } & \multicolumn{2}{|c|}{ Poland } & \multicolumn{2}{|c|}{ Azerbaijan } & \multicolumn{2}{|c|}{ Armenia } & \multicolumn{2}{|c|}{ Kazakhstan } \\
\hline & Initial & Final & Initial & Final & Initial & Final & Initial & Final & Initial & Final & Initial & Final \\
\hline CAHTI index & -1.1 & 1.8 & 1.6 & 4.2 & 0.0 & 2.5 & -1.5 & -2.4 & -1.3 & -2.2 & -1.3 & -2.3 \\
\hline Average GDP growth & \multicolumn{2}{|c|}{9.5} & \multicolumn{2}{|c|}{6.0} & \multicolumn{2}{|c|}{6.7} & \multicolumn{2}{|c|}{14.8} & \multicolumn{2}{|c|}{10.7} & \multicolumn{2}{|c|}{11.6} \\
\hline Wages & 370 & 899 & 335 & 1086 & 597 & 1425 & 149 & 313 & 43 & 211 & 110 & 440 \\
\hline Gasoline price & 0.33 & 1.27 & 0.74 & 1.28 & 0.55 & 1.16 & 0.44 & 0.72 & 0.51 & 0.90 & 0.32 & 0.52 \\
\hline Import & 533 & 5114 & 1817 & 24566 & 866 & 7497 & 220 & 1758 & 283 & 4190 & 523 & 2426 \\
\hline FDI & 15 & 289 & 407 & 493 & 106 & 272 & 48 & 216 & 7 & 85 & 67 & 233 \\
\hline Openness & 0.59 & 0.87 & 0.81 & 1.66 & 0.45 & 1.06 & 0.83 & 0.91 & 0.83 & 0.89 & 0.77 & 0.61 \\
\hline Inflation & 35.5 & 2.9 & 25.9 & 2.6 & 23.9 & 1.9 & 215.7 & 7.4 & 97.3 & 1.8 & 107.7 & 10.9 \\
\hline Unemployment & 7.3 & 4.5 & 6.1 & 3.9 & 12.8 & 4.4 & 0.8 & 5.0 & 8.0 & 16.7 & 6.2 & 4.9 \\
\hline Taxes & 0.28 & 0.25 & 0.40 & 0.37 & 0.38 & 0.34 & 0.14 & 0.16 & 0.13 & 0.21 & 0.12 & 0.17 \\
\hline $\begin{array}{l}\text { Human Development } \\
\text { index (HDI) }\end{array}$ & 0.81 & 0.69 & 0.74 & 0.84 & 0.75 & 0.87 & 0.61 & 0.75 & 0.61 & 0.76 & 0.67 & 0.82 \\
\hline Patents & 8.0 & 5.6 & 9.1 & 4.6 & 6.5 & 10.7 & 2.5 & 1.8 & 5.5 & 3.5 & 6.5 & 5.1 \\
\hline R\&D & 0.72 & 0.51 & 0.60 & 1.43 & 0.64 & 1.07 & 0.17 & 0.17 & 0.13 & 0.23 & 0.40 & 0.13 \\
\hline $\begin{array}{l}\text { Share of urban } \\
\text { population }\end{array}$ & 0.54 & 0.54 & 0.65 & 0.71 & 0.62 & 0.60 & 0.52 & 0.56 & 0.66 & 0.63 & 0.56 & 0.57 \\
\hline
\end{tabular}

Source: World Bank, UNCTAD. 

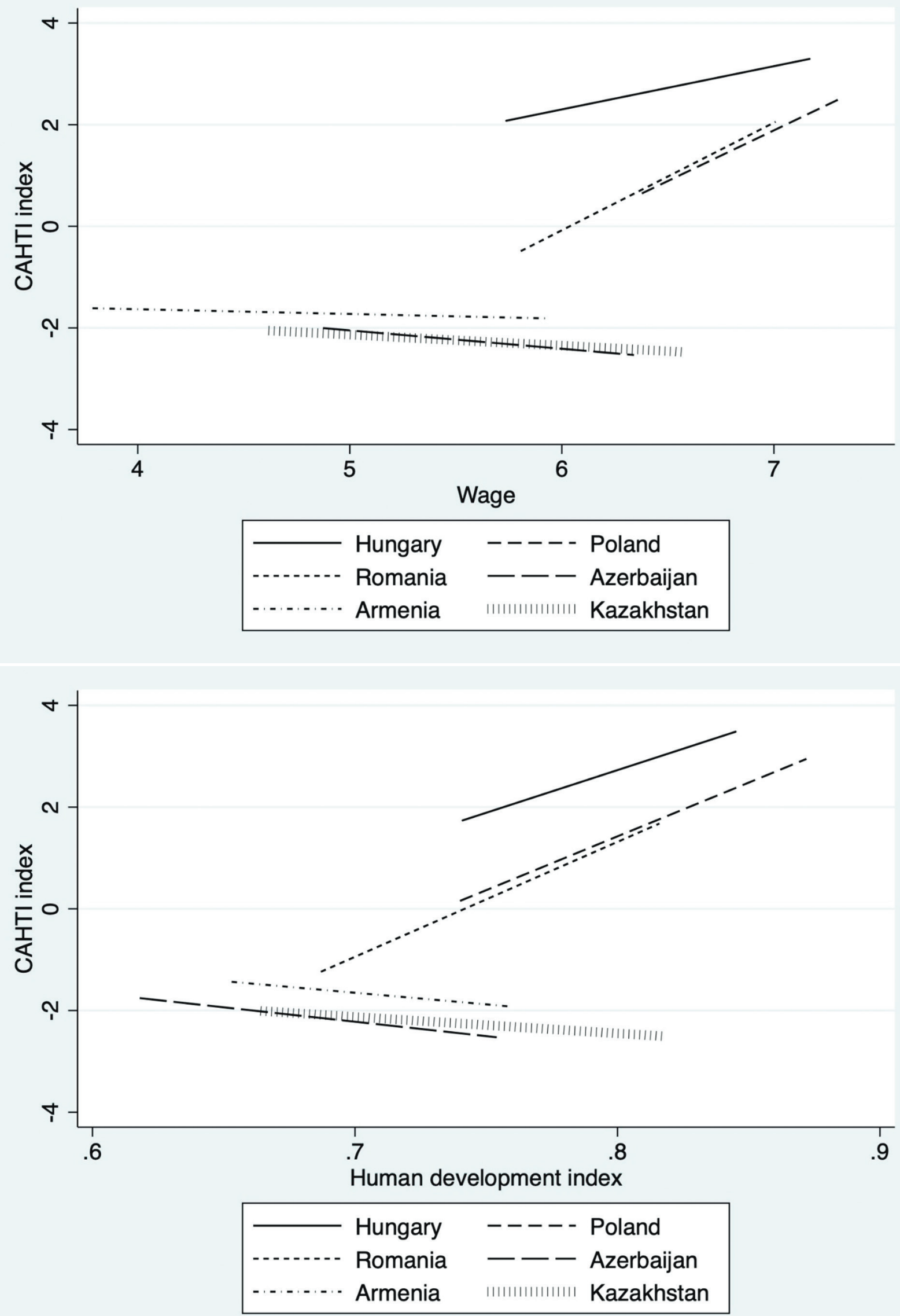

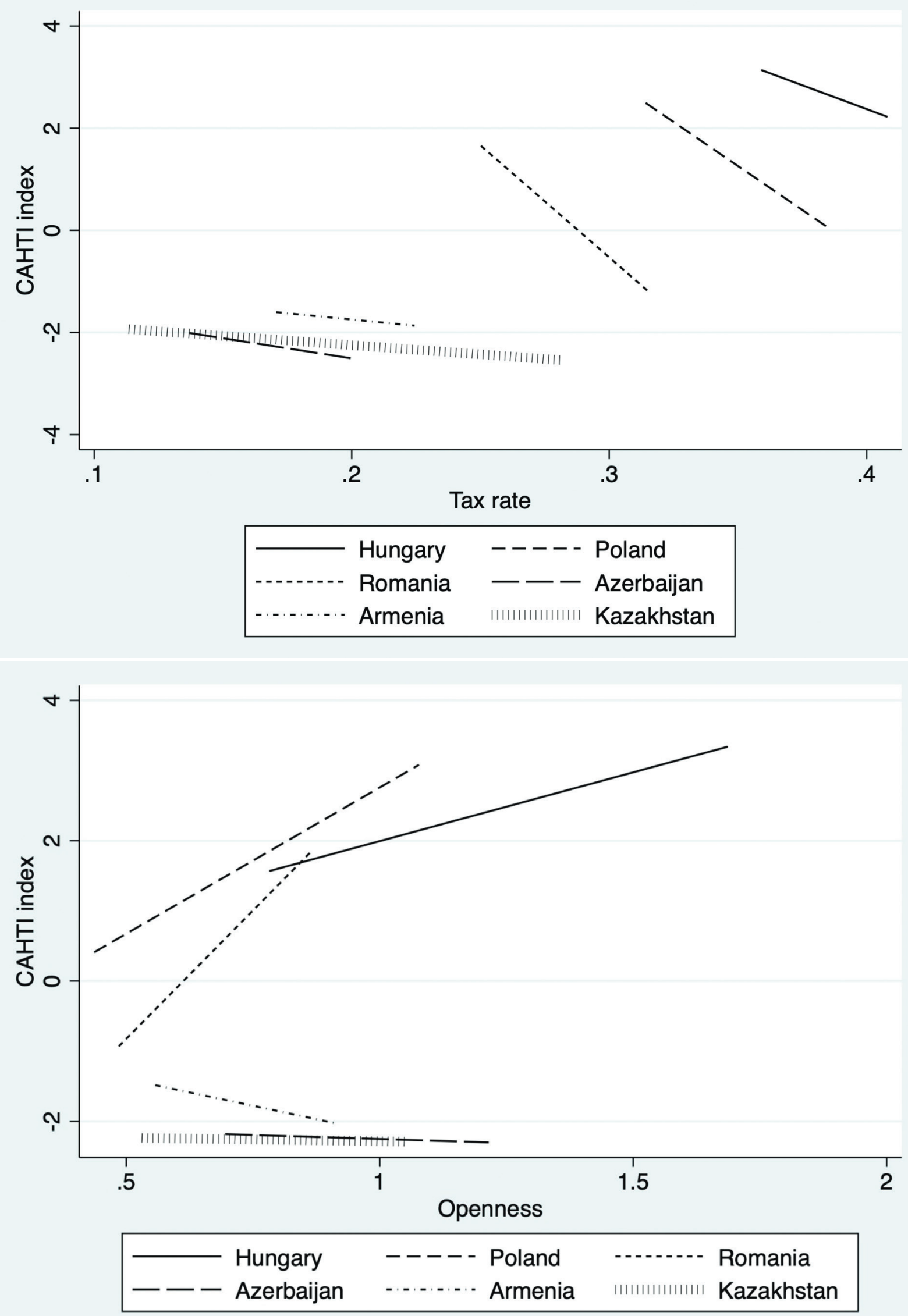

Fig. 1. Linear approximation of the values of wages, openness, tax rate and human development index in individual countries. Source: authors' calculations in the Stata package. 
index in the country. Thirdly, higher taxes have a negative impact on the volume of exports of hightech industries in the country. Finally, there is no obvious positive relationship between exports of high-tech industries and the level of $\mathrm{R} \& \mathrm{D}$, patents, and the quality of human capital.

For clarity, Figure 1 shows a linear approximation of the CAHTI index and four indicators in the studied countries, namely, wages, openness, tax rate and human development index. A negative slope of the graph means an increase in the considered indicator with a decrease in the CAHTI index, a positive slope indicates an increase in the indicator with an increase in the CAHTI index. The extreme points of each segment correspond to the minimum and maximum value of the considered indicator for the observation period. If the segment is to the right (left) of the others on the graph, then the range of values of the considered indicator in a specified country is higher (lower) compared to other countries.

\section{Multivariate Model and Methods of Analysis}

We believe that the groups of factors considered in this study have a simultaneous effect on the comparative advantage of the country's hightech industries. Since there is a mutual influence of various indicators of the country's development on each other, as well as simultaneous influence of factors on the dependent variable, it is necessary to build a multivariate regression model to obtain reliable research results.

The CAHTI index is the dependent variable in this model, and the variables presented in Table 2 are the regressors. For regression analysis, we use the method of least squares (OLS). Standard Wald, Breusch-Pagan and Hausman tests show the preference for using the OLS method with fixed effects. The model with fixed effects (within-estimators for each group in the model) was chosen due to the need to consider the unobservable and observable characteristics, which do not change over time and which can influence the variables used in the model. An analysis of pairwise correlations of dependent variables in the model showed the presence of a potential multicollinearity problem. In this regard, the specifications presented below did not simultaneously include variables with a value of the pairwise correlation coefficient greater than 0.5 . A variance inflation factor (VIF) test for multicollinearity was also conducted for each specification. The test showed the presence of heteroscedasticity in all specifications of the model. Therefore, all the standard errors of the regressor coefficients given below were obtained with a correction for heteroscedasticity.

\section{Results and Discussion}

Table 5 presents the results of assessing various specifications in the model. The table shows that the within determination coefficient varies in the range $0.26-0.36$, indicating a sufficiently high quality of the model for panel regression.

Hypothesis 1 that an increase in resource prices in the economy stimulates the export of high-tech industries is confirmed: coefficients of the variables of wages and gasoline prices have a positive sign with a high level of significance.

All indicators related to the country's foreign trade (the volume of imports and the indicator of openness) have a statistically significant positive effect on the CAHTI index. Simultaneously, there is no statistically significant positive effect of FDI on the dynamics of the CAHTI index. These results indicate that FDI is directed to sectors not related to the export of high-tech products.

Thus, the obtained data correspond to Hypothesis 2 that an increase of foreign trade openness in the country stimulates high-tech exports.

The unemployment rate in the country was found to be statistically significant among the considered macroeconomic factors. A negative relationship was discovered between the unemployment rate in the country and the volume of exports of high-tech products. At the same time, there is no statistically significant effect of the inflation rate on the dependent variable. Thus, Hypothesis 3 was partially confirmed in terms of the influence of the unemployment rate on the dependent variable. Regarding Hypothesis 4, tax rate was found to affect the CAHTI index negatively: an increase in the tax burden corresponds to a decrease in the export of high-tech products in the country.

Table 5 shows that the number of patents per capita and the share of R\&D expenditures in GDP are statistically insignificant in the model. The share of urban population in the country is also insignificant. At the same time, a higher level of human capital development is associated with a higher level of the CAHTI index in the model. In this regard, we can partially confirm Hypothesis 5.

Based on the obtained results, we formulated the following recommendations for the state policy of stimulating the export of high-tech products in the Russian economy.

1. Resource prices. An increase in the price of energy resources encourages national companies to invest in the modernisation of their production facilities, look for new market niches and offer products with high added value. An increase in the level of technological effectiveness of national in- 
Results of an assessment of factors affecting the country's high-tech exports

\begin{tabular}{|c|c|c|c|c|c|c|}
\hline & Model 1 & Model 2 & Model 3 & Model 4 & Model 5 & Model 6 \\
\hline Gasoline price & $\begin{array}{l}0.553^{* * *} \\
(0.197)\end{array}$ & & & & $\begin{array}{l}0.445^{* * *} \\
(0.156)\end{array}$ & \\
\hline Wages & & & $\begin{array}{l}0.264^{* *} \\
(0.111)\end{array}$ & & & $\begin{array}{l}0.265^{* *} \\
(0.111)\end{array}$ \\
\hline FDI & $\begin{array}{l}-0.075^{*} \\
(0.040)\end{array}$ & & & & & \\
\hline Import & & $\begin{array}{l}0.349^{* *} \\
(0.141)\end{array}$ & & & & \\
\hline Openness & $\begin{array}{l}0.798^{* * *} \\
(0.285)\end{array}$ & & $\begin{array}{l}1.033^{* * *} \\
(0.270)\end{array}$ & $\begin{array}{l}1.043^{* * *} \\
(0.297) \\
\end{array}$ & $\begin{array}{l}0.992^{* * *} \\
(0.261)\end{array}$ & $\begin{array}{l}1.004^{* * *} \\
(0.289) \\
\end{array}$ \\
\hline Unemployment & $\begin{array}{l}-0.019^{*} \\
(0.010)\end{array}$ & $\begin{array}{c}-0.029^{*} \\
(0.016)\end{array}$ & $\begin{array}{c}-0.032^{* * *} \\
(0.011)\end{array}$ & $\begin{array}{l}-0.022^{*} \\
(0.011)\end{array}$ & & $\begin{array}{c}-0.029^{* *} \\
(0.011)\end{array}$ \\
\hline Inflation & $\begin{array}{c}0.000 \\
(0.000) \\
\end{array}$ & $\begin{array}{c}0.000 \\
(0.001) \\
\end{array}$ & $\begin{array}{l}-0.000 \\
(0.001)\end{array}$ & & & $\begin{array}{l}-0.003 \\
(0.001) \\
\end{array}$ \\
\hline Tax rate & $\begin{array}{l}-3.217^{*} \\
(1.740)\end{array}$ & & $-4.219^{*}(2.235)$ & $\begin{array}{l}-3.277^{*} \\
(1.840) \\
\end{array}$ & $\begin{array}{c}-4.156^{* *} \\
(1.765) \\
\end{array}$ & \\
\hline Patents & $\begin{array}{l}-0.036 \\
(0.085) \\
\end{array}$ & $\begin{array}{c}0.045 \\
(0.072) \\
\end{array}$ & $\begin{array}{l}-0.051 \\
(0.085) \\
\end{array}$ & $\begin{array}{l}-0.053 \\
(0.081) \\
\end{array}$ & $\begin{array}{l}-0.051 \\
(0.083) \\
\end{array}$ & \\
\hline $\mathrm{R} \& \mathrm{D}$ & $\begin{array}{c}0.163 \\
(0.212) \\
\end{array}$ & & & & & $\begin{array}{c}0.224 \\
(0.195) \\
\end{array}$ \\
\hline HDI & & & & $\begin{array}{c}4.183^{*} \\
(2.216) \\
\end{array}$ & & \\
\hline Agglomeration effect & $\begin{array}{l}-2.856 \\
(5.982) \\
\end{array}$ & $\begin{array}{c}0.184 \\
(5.924) \\
\end{array}$ & $\begin{array}{l}-0.643 \\
(5.318) \\
\end{array}$ & $\begin{array}{l}-3.588 \\
(5.194) \\
\end{array}$ & $\begin{array}{l}-1.000 \\
(5.955) \\
\end{array}$ & \\
\hline$R$-sq. & 0.39 & 0.26 & 0.37 & 0.35 & 0.38 & 0.35 \\
\hline Observations & 401 & 480 & 480 & 502 & 485 & 517 \\
\hline Mean VIF & 1.64 & 1.21 & 1.40 & 1.52 & 1.33 & 1.35 \\
\hline
\end{tabular}

Note. Standard errors in parentheses; ${ }^{* * *} p<0.01,{ }^{* *} p<0.05,{ }^{*} p<0.1$.

Source: authors' calculations in the STATA computer package.

dustries results in an increase in exports of products with high added value. Russian state tariff policy should stimulate further liberalisation of energy markets and services of natural monopolies, as well as introduce market incentives for the implementation of energy-saving measures.

Even though wages are one of the types of costs for companies, manufacturers of high-tech products are not under significant pressure from rising wages in the economy [38]. On the contrary, the increase in the population's income leads to a long-term change in the ratio of lowskilled and high-skilled jobs in the economy, a reduction in the share of upstream sectors and an increase in the share of high-tech sectors. In this regard, the state policy aimed at increasing the income of the population will contribute to the increase of high-tech exports in the economy in the long term.

2. Foreign economic factors. The growth of the economy's foreign trade openness leads to an increase in its high-tech exports. Since $70 \%$ of world trade at the moment occurs in global value chains, the efforts of government authorities should be aimed at eliminating the one-sided participation of Russia in the GVCs (as a supplier of raw materials and upstream products). The growth of the country's exports depends on the volume of imports: new technologies are imported into the country along with necessary components, stimulating the growth of technological effectiveness of production [39].

The effective tools of integrating the country into global value chains include the involvement of MNCs in the economy, the development of export-related industries, and the development of platform solutions for business. At the level of individual companies, the following tools can be used: direct support of exporting firms, stimulation of the modernisation of national companies and their susceptibility to innovation, support of the creation of new industries focused on global demand. The support of fast-growing companies, as well as small and medium-sized exporting companies, plays an important role in changing the structure of exports of a developing economy [40]. 
3. Macroeconomic factors. Lower tax rate is associated with higher exports of high-tech products. The system of tax incentives in the Russian economy is quite diverse and includes the following: depreciation of capital investments; value added tax (VAT) exemption when performing R\&D at the expense of state budgets and special funds; VAT exemption on the import of technological equipment that has no equivalents in Russia; multiplier for R\&D expenditures, etc. Simultaneously, the share of enterprises using such support is small, and the support is often biased towards companies that are close to the public sector [41]. We consider it advisable to expand tax and other financial incentives among national exporters. The toxicity of state support measures is another well-known problem, which requires solution. This problem includes an increasing complexity of reporting, attracting the attention of supervisory authorities, an increasing number of inspections, etc.

4. Human capital. The quality of human capital is the most important factor in the creation of products and technologies that are competitive on international markets. Moreover, an increase in the quality of human capital is a factor in the diversification of exports in resource-dependent countries [42]. An increase in the quality of human capital in Russia is a long-term investment, primarily by the state, in such sectors as education, healthcare and social support system. Technological transformation and improvement of the quality of services in these sectors are the basis of the policy for increasing the quality of human capital in Russia. In addition, the state policy should focus on increasing the population mobility and changing the existing labour market model [43]. The role of enterprises in improving the qualifications of workers seems to be significant. In this regard, it is expedient to create a system of tax and financial instruments that encourage enterprises to implement training programmes for their employees [44].

\section{Conclusion}

The study analyses the factors influencing the level of exports of high-tech industries in 27 countries of Eastern Europe and the CIS from 1995 to 2018. The Balassa Index was used to measure the volume of exports at the industry level in the country. The index is calculated as the proportion of exports in a specific industry in the total export of a country divided by the proportion of exports in this industry in the structure of exports of all countries in the world. The analysis uses data on 73 industries divided in the following groups: automotive, chemical, mechanical engineering, electronics, and electrical engineering. To conduct regression analysis using the principal component method, the data on all industries in each country in a specific year was combined into one indicator of comparative advantage of high-tech industries.

A descriptive analysis of the CAHTI indicator showed that three leading countries in terms of high-tech exports - the Czech Republic, Hungary, and Slovenia - stood out at the beginning of the observation period in the considered group of countries. However, at the end of the observation period, all countries were clearly divided into two groups. The countries of Central and Eastern Europe, as well as the Baltic countries, showed a significant increase in the CAHTI index, while other countries of the former USSR experienced a decrease or stagnation of this indicator.

The article analyses the impact of resource-related, foreign economic, macroeconomic, and innovative factors on the change in the CAHTI index.

The panel regression method with fixed effects allowed us to obtain the following results. First, it is shown that the high resource price in the country (in particular, the level of wages and gasoline prices) stimulates production in hightech industries. Second, the growth of the country's foreign trade openness stimulates the export of goods with high added value. Third, there is no positive relationship between foreign direct investment and the CAHTI index due to the fact that FDI in these countries is not directed to hightech industries. Fourth, a statistically significant negative relationship is revealed between the unemployment rate in the country and the output in high-tech industries. Fifth, increase in the tax burden in the country puts significant pressure on the production volume of high added value goods. Sixth, there is a statistically significant impact of the quality of human capital on the increase of the CAHTI index in the analysed countries.

We believe that if public authorities use the results obtained in this study to develop various programmes and measures aimed at supporting high-tech exports, the effectiveness of state policy in this field will increase.

The results presented in this study can serve as a basis for further research. Firstly, alternative, complex indicators can be used as variables reflecting the volume of exports of high-tech industries in the economy. Secondly, a different sample of countries can be used to identify the determinants of export growth in high-tech industries, allowing conclusions to be drawn for countries with other similarities. Thirdly, other industries and 
other groups of factors can be used to examine the determinants of exports. Finally, an analysis of ex-

port factors at the industry level in regions of a country or a group of countries can be conducted.

\section{References}

1. Tinbergen, J. (1962). An Analysis of World Trade Flows. Shaping the World Economy. N.Y.: Twentieth Century Fund, 330.

2. Anderson, J. \& van Wincoop, E. (2003). Gravity with Gravitas: A Solution to the Border Puzzle. American Economic Review, 93(1), 170-192. DOI: 10.1257/000282803321455214

3. Egger, P., (2002). An Econometric View of the Estimation of Gravity Models and the Calculation of Trade Potentials. The World Economy, 25(2), 297-312. DOI: 10.1111/1467- 9701.00432

4. Silva, J. M. C. S. \& Tenreyro, J. (2006). The Log of Gravity. The Review of Economics and Statistics, 88(4), 641-658. DOI: 10.1162/rest.88.4.641.

5. Kónya, I. (2006). Modelling Cultural Barriers in International Trade. Review of International Economics, 14(3), 494507. DOI: $10.1111 /$ j.1467-9396.2006.00626.x.

6. Gómez-Herrera, E. (2013). Comparing Alternative Methods to Estimate Gravity Models of Bilateral Trade. Empirical Economics: A Journal of the Institute for Advanced Studies, 44(3), 1087-1111.

7. Francois, J. \& Manchin, M. (2013). Institutions, Infrastructure, and Trade. World Development, 46, 165-175. DOI: 10.1016/j.worlddev.2013.02.009.

8. Gustavsson, P., Hansson, P. \& Lundberg, L. (1999). Technology, resource endowments and international competitiveness. European Economic Review, 43, 1501-1530. DOI: 10.1016/S0014-2921(98)00027-0.

9. Naudé, W. \& Gries, T. (2009). Explaining Regional Export Performance in a Developing Country: The Role of Geography and Relative Factor Endowments. Regional Studies, 43(7), 967-979. DOI: 10.1080/00343400801932300

10. Marconi, D. \& Rolli, V. (2008). Comparative Advantage Patterns and Domestic Determinants in Emerging Countries: An Analysis with a Focus on Technology. World Institute for Development Economic Research (UNU-WIDER), Working Papers, 34 .

11. Thangamani, B. (2016). The Determinants of Export Performance: The Case of Sri Lanka. International Research Journal of Social Sciences, 5, 8-13.

12. Agosin, M., Alvarez, R. \& Bravo-Ortega, C. (2012). Determinants of export diversification around the world: 19622000. The World Economy, 35(3), 295-315. DOI: 10.1111/j.1467-9701.2011.01395.x.

13. IMF. (2014). Sustaining Long-Run Growth and Macroeconomic Stability in Low-Income Countries: The Role of Structural Transformation and Diversification. IMF Policy Paper, Washington, The International Monetary Fund, 53.

14. Parteka, A. \& Tamberi, M. (2013). What Determines Export Diversification in the Development Process? Empirical Assessment. The World Economy, 36, 807-826. DOI: 10.1111/twec.12064.

15. Mau, K. (2014). Margins, Gravity, and Causality: Export Diversification and Income Levels. GIGA Working Paper No. 249, 35 .

16. Iwamoto, M. \& Nabeshima, K. (2012). Can FDI promote export diversification and sophistication of host countries? Dynamic panel system GMM analysis. IDE Discussion Paper No. 347. Chiba: IDE/JETRO, 38.

17. Banga, R. (2006). The export-diversifying impact of Japanese and US foreign direct investments in the Indian manufacturing sector. Journal of International Business Studies, 37(4), 558-568. DOI: 10.1057/palgrave.jibs.8400207.

18. Gorg, H., \& Greenaway, D. Much Ado about Nothing? (2004). Do domestic firms really benefit from foreign direct investment? World Bank Research Observer, 19(2), 171-197. DOI: 10.1093/wbro/lkh019.

19. Hoekman, B. \& Djankov, S. (1997). Determinants of the Export Structure of Countries in Central and Eastern Europe. The World Bank Economic Review, 11(3), 471-487.

20. Bas, M. \& Strauss-Kahn, V. (2015). Input-trade liberalization, export prices and quality upgrading. Journal of International Economics, 95(2), 250-262. DOI: 10.1016/j.jinteco.2014.12.005.

21. Puga, D. \& Trefler, D. (2010). Wake up and smell the ginseng: International trade and the rise of incremental innovation in low-wage countries. Journal of Development Economics, 91(1), 64-76. DOI: 10.1016/j.jdeveco.2009.01.011.

22. Balogh, J. \& Jambor, A. (2017). Determinants of revealed comparative advantages: the case of Cheese trade in the European Union. Acta Alimentaria, 46(3), 304-311. DOI: 10.1556/066.2016.0012.

23. OECD. (2005). Science, Technology and Industry Scoreboard: Benchmarking Knowledgebased Economies. Paris, 261. DOI: $10.1787 /$ sti_scoreboard-2015-en.

24. Sulaiman, M. \& Saad, N. (2009). An Analysis of Export Performance and Economic Growth of Malaysia using CoIntegration and Error Correction Models. Journal of Developing Areas, 43(1), 217-231. DOI: 10.1353/jda.0.0031

25. Muratoğlu, G. \& Muratoğlu, Y. (2016). Determinants of Export Competitiveness: Evidence from OECD Manufacturing. Journal of Economics and Political Economy, 3(1), 111-118. DOI: 10.1453/jepe.v3i1.659

26. Blomstrom, M. \& Kokko, A. (2003). From natural resources to high-tech production: the evolution of industrial competitiveness in Sweden and Finland. International trade, CEPR Discussion Paper № 3804, 37.

27. LiPuma, J., Newbert, S. \& Doh, J. (2013). The effect of institutional quality on firm export performance in emerging economies: a contingency model of firm age and size. Small Business Economics, 40(4), 817-841. DOI: 10.1007/s11187011-9395-7. 
28. Nguyen, S. \& Wu, Y. (2020). Governance and Export Performance in Vietnam. Journal of Southeast Asian Economies, 37(1), 1-25. DOI: $10.2307 / 26938858$.

29. Li, J., Vertinsky, I. \& Zhang, H. (2013). The Quality of Domestic Legal Institutions and Export Performance: Theory and Evidence from China. MIR: Management International Review, 53(3), 361-390. DOI: 10.1007/s11575-012-0146-z.

30. Duranton, G. \& Puga, D. (2004). Micro-foundations of urban agglomeration economies. In: J. V. Henderson, J.-F. Thisse (Eds.), Handbook of Urban and Regional Economics. Volume 4 (pp. 2063-2117). North-Holland, Amsterdam.

31. Balassa, B. (1965). Trade liberalization and 'Revealed' comparative advantage. Manchester School of Economic and Social Studies, 33, 99-123.

32. Lall, S. (2000). The Technological Structure and Performance of Developing Country Manufactured Exports, 19851998. Oxford Development Studies, 28(3), 337-369. DOI: 10.1080/713688318.

33. Jolliffe, I. (2002). Principal Component Analysis. Second Edition. New York, NY: Springer New York, 488. DOI: $10.1007 /$ b98835.

34. Vyas, S. \& Kumaranayake L. (2006). Constructing socio-economic status indices: how to use principal components analysis. Health Policy and Planning, 21(6), 459-468. DOI: 10.1093/heapol/czl029.

35. Loko, B. \& Diouf, M. (2009). Revisiting the Determinants of Productivity Growth: What's New? IMF Working Papers, 29. DOI: $10.5089 / 9781451873726.001$.

36. Zheng, Z., Podobnik, B. \& Feng, L. (2012). Changes in Cross-Correlations as an Indicator for Systemic Risk. Scientific Reports 2, 888, 1-9. DOI: 10.1038/srep00888.

37. Choi, J., Lee, S. \& Amir, S. (2016). The effects of institutional distance on FDI inflow: General environmental institutions (GEI) versus minority investor protection institutions (MIP). International Business Review, 25(1), 114-123. DOI: 10.1016/j.ibusrev.2014.11.010.

38. Xiong, Y. \& Zhang, S. (2017). The Impact of Rising Labor Costs on Commodity Composition of Manufactured Exports: Evidence from China. American Economic Association, Working Paper, 37.

39. Fedyunina, A. \& Averyanova, Y. (2018). Empirical Analysis of Competitiveness Factors of Russian Exporters in Manufacturing Industries. Ekonomicheskaya Politika [Economic Policy], 13, 102-121. DOI: 10.18288/1994-5124-2018-6102-121. (In Russ.)

40. Simachev, Yu., Fedyunina, A. \& Kuzyk, M. (2020). Rossiya v globalnom proizvodstve. Doklad $k$ XXI Aprelskoy mezhdunarodnoy nauchnoy konferentsii po problemam razvitiya ekonomiki i obshchestva [Russia in the Global Production. Presentation for XXI April International Academic Conference on Economic and Social Development]. Moscow: HSE Publishing House, 148. (In Russ.)

41. Simachev, Yu. \& Kuzyk, M. (2020). State support of enterprises in Russia: Beneficiaries and effects. Voprosy Ekonomiki, 3, 63-83. DOI: 10.32609/0042-8736-2020-3-63-83. (In Russ.)

42. Lashitew A., Ross M., \& Werker E. (2020). What Drives Successful Economic Diversification in Resource-Rich Countries? The World Bank Research Observer, 33. DOI: 10.1093/wbro/lkaa001.

43. HSE. (2018). Kak uvelichit chelovecheskiy kapital i ego vklad v ekonomicheskoe i sotsialnoe razvitie. Tezisy doklada $k$ XIX Aprelskoy mezhdunarodnoy nauchnoy konferentsii po problemam razvitiya ekonomiki $i$ obshchestva [How to increase human capital and its contribution to economic and social development. Thesis of presentation for XIX April International Academic Conference on Economic and Social Development]. Moscow: HSE Publishing House, 64. (In Russ.)

44. Simachev, Yu., Daniltsev, A., Fedyunina, A., Glazatova, M., Kuzyk, M. \& Zudin N. (2019). Russia in the changing conditions of world trade: A structural view at the new positioning. Voprosy Ekonomiki, 8, 5-29. DOI: 10.32609/00428736-2019-8-5-29. (In Russ.)

\section{About the authors}

Igor M. Drapkin — Dr. Sci. (Econ.), Professor, Academic Department of International Economics and Management, Ural Federal University; Scopus Author ID: 57191611854; http://orcid.org/0000-0002-5989-8463 (19, Mira St., Ekaterinburg, 620002, Russian Federation; e-mail: i.m.drapkin@mail.ru).

Anna A. Gainetdinova - Master Student, Ural Federal University (19, Mira St., Ekaterinburg, 620002, Russian Federation; annagaynetdinova9@yandex.ru).

Aksanat Zh. Panzabekova - Cand. Sci. (Econ.), Associate Professor, Chief Research Associate, Institute of Economics SC MES RK; Scopus Author ID: 57219146750; http://orcid.org/0000-0002-6389-9637 (29, Kurmangazy St., Almaty, 050010, Republic of Kazakhstan; e-mail: aksanat@mail.ru.

\section{Информация об авторах}

Драпкин Игорь Михайлович - доктор экономических наук, профессор, кафедра международной экономики и менеджмента, Уральский федеральный университет имени первого Президента России Б. Н. Ельцина; Scopus Author ID: 57191611854; http://orcid.org/0000-0002-5989-8463 (Российская Федерация, 620002, г. Екатеринбург, ул. Мира, 19; e-mail: i.m.drapkin@mail.ru).

Гайнетдинова Анна Андреевна - магистрант, Уральский федеральный университет имени первого Президента России Б. Н. Ельцина (620002, г. Екатеринбург, ул. Мира 19); e-mail: annagaynetdinova9@yandex.ru. 
Панзабекова Аксанат Жакитжановна - кандидат экономических наук, доцент, главный научный сотрудник, Институт экономики КН МОН РК; Scopus Author ID: 57219146750; http://orcid.org/0000-0002-6389-9637 (Республика Казахстан, 050010, г. Алматы, ул. Курмангазы, 29; e-mail: aksanat@mail.ru).

Дата поступления рукописи: 08.10.2020.

Прошла рецензирование: 17.11.2020.

Принято решение о публикации: 23.03.2021.

Received: 08 Oct 2020

Reviewed: 17 Nov 2020

Accepted: 23 Mar 2021 